\title{
In vitro screening for growth inhibition activity on cancer cell lines of northern Chile highlands shrubs
}

\section{Luis Bustos González ${ }^{12^{*}}$ Mario Juan Simirgiotis ${ }^{3}$ Claudio $^{\circledR}$ Parra $^{1} @$ Susana Alfaro-Lira $^{1} @$ Emilio Soto ${ }^{1}$ Carlos Echiburú-Chau ${ }^{1,4}(\mathbb{C}$}

${ }^{1}$ Centro de Investigaciones del Hombre en el Desierto (CIHDE), Arica, Chile.

${ }^{2}$ Escuela de Medicina, Facultad de Ciencias de la Salud, Universidad de Tarapacá, Arica, Chile. E-mail: luisbustosg@gmail.com. ${ }^{*}$ Corresponding author.

${ }^{3}$ Instituto de Farmacia, Facultad de Ciencias, Universidad Austral de Chile, Campus Isla Teja 5090000, Valdivia, Chile.

${ }^{4}$ Facultad de Ciencias de la Salud, Universidad de Tarapacá, Arica, Chile.

ABSTRACT: Cancer is still one of the leading causes of death worldwide. Many chemotherapeutics from plants have been tested in cancer, such as vinblastine and paclitaxel. The north of Chile, Arica \& Parinacota region, is characterized by its vegetal biodiversity due to its unique geographical and climatological conditions, offering an unexplored and unique source of naturally-derived compounds. The present research has considered a screening of 26 highland herbs using an in vitro growth inhibition model in a panel of six cancer cell lines from different tissues. 5 of the 26 studied ethanolic extracts shows strong activity at least in one cell line when tested at $10 \mu \mathrm{g} \mathrm{mL}^{-1}$. We present a group of plants worthy to be evaluated as promissory extracts. This work is part of the systematic attempt to find new candidates to be used in cancer therapies.

Key words: Growth Inhibition, anticancer activity, highland medicinal plants, ethanolic extract, bioprospecting, northern Chile, Arica y Parinacota.

Triagem in vitro da atividade de inibição do crescimento em linhagens celulares de câncer em arbustos das montanhas do norte do Chile

RESUMO: O câncer ainda é uma das principais causas de morte no mundo. Muitos quimioterápicos de plantas foram testados em câncer, como vinblastina e paclitaxel. $O$ norte do Chile, região de Arica e Parinacota, caracteriza-se por sua biodiversidade vegetal devido às suas condições geográficas e climatológicas únicas, oferecendo uma fonte inexplorada e única de compostos de origem natural. A presente pesquisa considerou uma triagem de 26 ervas das terras altas usando um modelo de inibição de crescimento in vitro em um painel de seis linhas celulares de câncer de diferentes tecidos. Cinco, dos 26 extratos etanólicos estudados, mostram forte atividade pelo menos em uma linhagem celular quando testados a $10 \mu \mathrm{g} \mathrm{mL-1.} \mathrm{Apresentamos} \mathrm{um} \mathrm{grupo} \mathrm{de} \mathrm{plantas} \mathrm{dignas} \mathrm{de} \mathrm{serem} \mathrm{avaliadas} \mathrm{como} \mathrm{extratos} \mathrm{promissórios.}$ Este trabalho faz parte da tentativa sistemática de encontrar novos candidatos para serem usados em terapias contra o câncer.

Palavras-chave: inibição do crescimento, atividade anticâncer, plantas medicinais das terras altas, extrato etanólico, bioprospecção, norte do Chile, Arica e Parinacota.

\section{INTRODUCTION}

Cancer is still one of the leading causes of death in the world. Its high incidence, mortality and lack of effective treatment have led to a permanent effort in bioprospecting for new chemotherapeutics. The estimated annual incidence of cancer in Chile is approximately 35,000 new cancer cases per year, with adjusted incidence rates of 226 and 180 per 100,000 male and female inhabitants, respectively (JIMENEZ DE LA JARA et al., 2015). Therefore, the research and development of new, more effective and less toxic substances against cancer have become an essential. Worldwide, many plants have been tested in cancer models and found to be effective as anticancer agents. Several of them have been used routinely as anticancer drugs, such as vinblastine and paclitaxel, both compounds extracted from Catharanthus roseus and Taxus brevifolia, respectively (CISTERNINO et al., 2003; MAKAROV et al., 2007). Several other drugs extracted from plants have recently proved to be useful as anti-cancer therapies, including betolunic acid (FULDA, 2008), resveratrol (GARCÍAZEPEDA et al., 2013) and homoharringtotine (LÜ \& WANG, 2014), among others. The north of Chile is characterized by its vegetal biodiversity due to a 
unique geographical and climatological conditions (e.g., altitudes from zero to 5000 m.a.s.l; temperatures of $23{ }^{\circ} \mathrm{C}$ to $-5{ }^{\circ} \mathrm{C}$ and high solar radiation), offering an unexplored a unique source of naturally derived compounds. Most of these, recognized as medicinal herbs, are part of the traditional uses in folk medicine given by the local Andean communities (VILLAGRÁN et al., 2003; FERREIRA-MACHADO et al., 2004). However, efforts in additional studies of these plants about new potential healing properties, not necessarily linked to its ancestral uses, have not been carried out in-depth yet. As part of a permanent effort of our laboratory, we have focused our work in bioprospecting activities. We have found two Andean species with promising anticancer activities. For example, the ethanolic extract of Senecio nutans, was able to induce cytotoxicity in breast cancer cells but not in MCF-10F, the normal counterpart, showing an interesting differential effect (ECHIBURÚCHAU, 2014). On the other hand, the benzofurane p-coumaryloxytremetone isolated from Parastrephia lucida, showed a protective activity from reactive oxygen species (ROS) when tested in MCF10F after pyocyanin treatment (ECHIBURU-CHAU et al., 2017) and recently we presented a first glance of cytotoxic activity of the Bacharis alnifolia infusion and ethanolic extract (SOTO et al., 2019). The present research has considered a screening of twenty-six Andean plants, from Arica \& Parinacota region, northern Chile, using an in vitro growth inhibition model in a panel of six cancer cell lines derived from different tissues (colorectal, liver, breast, lung, kidney and skin). The plants were selected by its popular use in local communities and its availability at local markets.

\section{MATERIALS AND METHODS}

\section{Plant material}

Fresh aerial parts of the 26 plants (Table 1), from the Andean Highlands sector at the Arica and Parinacota Region, northern Chile, were obtained from the local market "Terminal Agropecuario Arica"

Table 1 - Ethnobotanical data of the studied Andean plants.

\begin{tabular}{|c|c|c|}
\hline Plant specie and common name & Traditional uses & Most representative chemical constituents \\
\hline Aloysia tarapacana (Rika Rika) & Cold, anti-inflammatory & Terpenes \\
\hline Azorella compacta (Llareta) & Diuretic, analgesic & Polyphenols \\
\hline Baccharis tola (Ñacatola) & Gastro protective, Antiseptic & Flavonoids, Tremetones \\
\hline Baccharis genistelloides (Kimsakusho) & Liver problems, diabetes & Flavonoids, Diterpenes \\
\hline Bidens andicola (Misico) & Contraceptive, anti-rheumatic & Quercetin glycosides \\
\hline Cynodon dactylon (Grama) & Diabetes, cancer & Alkaloids, Flavonoids \\
\hline Dunalia spinosa (Yara) & Diabetes, high altitude sickness & (E)-aurone, withaferin-A \\
\hline Ephedra breana (Pingo Pingo) & Anti-asthmatic, diuretic & Phenolic acids, Proanthocyanidins \\
\hline Equisetum giganteum (Cola de caballo) & Diuretic, anti-inflammatory & Flavonoids, Phenolic acids \\
\hline Fabiana densa (Tolilla) & Anti-inflammatory, lung disease & Diterpenoids, Flavonoids \\
\hline Lampaya medicinalis (Lampaya) & Colds, stomach pain & p-hydroxyacetophenone derivatives \\
\hline Malva parviflora (Malva) & Anti-inflammatory, antibacterial & Oleanoic acid derivative, $\beta$-sitosterol \\
\hline Mutisia acuminata (Chinchircoma) & Antiseptic, cancer & Arbutin, Flavonoids \\
\hline Origanum vulgare (Oregano) & Antimicrobial, antifungal & Terpenes, Phenolic acids \\
\hline Phyla nodiflora (Tiquil-Tiquil) & Immunomodulator, anti-inflammatory & Flavonoids, Alkaloids \\
\hline Polylepis rugulosa (Queñoa) & Respiratory diseases, diabetes & Oleanoic and Ursolic acid derivatives \\
\hline Polylepis tarapacana (Queñoa colchane) & Respiratory diseases, diabetes & Oleanoic and Ursolic acid derivatives \\
\hline Psoralea glandulosa (Culén) & Antiseptic, antimicrobial & Bakuchiols, Furanocumarins \\
\hline Rosmarinus officinalis (Romero) & Antispasmodic, diabetes & Diterpernes, Flavonoids \\
\hline Clinopodium gilliesii (Muña) & Digestive disorders, altitude sickness & Terpenes, Flavonoids \\
\hline Senecio zoellneri (Lobesilla) & Wound healing & Tremetone, Terpenes \\
\hline Solanum nitidum (Nuñumaya) & Parasites, "badair" condition & No reports \\
\hline Tagetes multiflora (Suico) & Stomach ache, urinary & Terpenes, Flavonoids \\
\hline Aldama helianthoides (Sorona) & Anti-rheumatic, cancer & Flavonoids, Simple phenolics \\
\hline Verbena litoralis (Verbena) & Diarrhea, STDs & Iridioids, Chalconoids, \\
\hline Xenophyllum poposum (Poposa) & Hypertension, altitude sickness & Alkaloids, Flavonoids \\
\hline
\end{tabular}


(ASOCAPEC). Collected samples and voucher numbers were deposited in the herbarium of the Centro de Investigaciones del Hombre en el Desierto (CIHDE), Arica, Chile.

\section{Preparation of extracts}

The samples were treated as previously described (PARRA et al., 2018). Dried and powdered samples (1 g of aerial parts) were macerated with absolute ethanol for 72 hours at room temperature. The extracts were filtered using a Whatman filter paper $\mathrm{N}^{\mathrm{o}} 1$ and concentrated on a rotary evaporator under reduced pressure at $40{ }^{\circ} \mathrm{C}$. The residues were re-dissolved in EtOH 97\% to yield a final concentration of $1 \mathrm{mg} \mathrm{mL} \mathrm{mL}^{-1}$. The samples were refrigerated at $20^{\circ} \mathrm{C}$ until its use.

\section{Cell culture}

Six cells lines were used, A549 (Human lung carcinoma), B-16 (Murine melanoma), Caco2 (Human colorectal adenocarcinoma), HEK293 (Human embryo kidney), HepG2 (Human liver carcinoma) and MCF7 (Human breast adenocarcinoma). All cell lines were cultured in DMEM medium supplemented with $10 \%$ of fetal bovine serum (Hyclone, South Logan, Utah, U.S), only when it was necessary the medium was supplemented with $100 \mathrm{mg} \mathrm{mL}^{-1}$ streptomycin, $2.5 \mathrm{mg} \mathrm{mL}^{-1}$ amphotericin B (all from Corning, Tewksbury, MA, USA), The incubation condition was established at $37{ }^{\circ} \mathrm{C}$, humid atmosphere and $5 \%$ $\mathrm{CO}_{2}$. (ECHIBURÚ-CHAU, 2014).

\section{In vitro growth inhibition screening}

To measure growth inhibition effects, cell viability was assessed using MTT assay. Cells were seeded for 1 day prior to exposure in a 96-well format in sextuplicate, for A549, Caco-2, MCF7 and HepG2 10,000 cells per well were seeded, and 20,000 cells/ well for HEK-293 and B-16 cell lines. After this incubation period, culture medium was discarded and cells were washed with sterile DPBS, and replaced with two concentrations of ethanolic extracts (10 and $\left.100 \mu \mathrm{g} \mathrm{mL}^{-1}\right)$ in DMEM medium without FBS for a period of 24 hours at same incubation conditions established before.

Afterthisperiod,culturemediumwithextract treatments was discarded and replaced with $200 \mu \mathrm{L}$ MTT medium (1,2 mM of 3-(4,5-dimethylthiazol-2yl)-2,5-diphenyltetrazolium bromide] in DMEM medium without serum), and incubated for $2.5 \mathrm{~h}$ at $37^{\circ} \mathrm{C}$ and 5\% CO (KUMAR et al., 2018). An amount of $200 \mu \mathrm{L}$ of DMSO was used for solubilizing the formazan crystals and incubate cells for 15 minutes at $37^{\circ} \mathrm{C}$.. The absorbance was measured with a TECAN Infinite pro 200 plate reader at $560 \mathrm{~nm}$. The viability percentage was calculated against a non-drug treated control (designated $100 \%$ viability) considered as a control vehicle $(\leq 0.5 \% \mathrm{DMSO})$. For background absorption, some wells remained cell-free with DMSO as a blank control.

\section{Statistical analysis}

Data were analyzed using GraphPad 6.0 software for Windows. The experimental data were expressed as means $\pm \mathrm{SD}$; the comparisons were made between controls and treated cultures using a oneway ANOVA followed by Dunnett's post-hoc test for multiple comparisons. $p<0.05$ was considered to indicate a statistically significant difference between values.

\section{RESULTS AND DISCUSSION}

Five plant extracts (Rosmarinus officinalis, Cynodon dactylon, Dunalia spinosa, Psoralea glandulosa and Azorella compacta) exhibited the highest cytotoxicity (cell viability $\leq 50 \%$ ), at $10 \mu \mathrm{g}$ $\mathrm{mL}^{-1}$ at least in one cell line, representing the $18.5 \%$ of the total plants (Table 2). A. compacta shows to be active against MCF7 (50.0 \pm 9.0$),$ HEK-293 (43.6 $\pm 14.2)$ and $\mathrm{B} 16(11.4 \pm 7.1)$, is effective in a major range of cell lines; $R$. officinalis was active for HEK$293(59.0 \pm 11.7)$ and B16 (30.0 \pm 8.3$)$. C. dactylon shows a cytotoxic effect only in HepG2 (31.8 \pm 5.1$)$; Finally, D. spinosa and $P$. glandulosa show activity only against B16 cell lines $(38.0 \pm 6.6$ and $44.5 \pm 6.2$, respectively). Previously, we isolated an azorellane diterpene from $A$. compacta with cytotoxic activity, showing to be effective on breast cancer cells (MCF7) after $24 \mathrm{~h}$ exposure (BÓRQUEZ et al., 2016).

Now the spectrum of potential studies expands for new cancer types. D. spinosa was only active against melanoma B16 cell line. Supporting these results, these species have reports of an isolated active metabolite, withaferin A (ERAZO et al., 2008). A steroidal lactone that has been reported as an inhibitor of cell proliferation of uveal melanoma cells with an $\mathrm{IC}_{50}$ value of $2,42 \mu \mathrm{M}$, also shifts $\mathrm{G}_{2} / \mathrm{M}$ cell cycle arrest, and induces apoptosis in multiple cell lines in vitro and decreases melanoma tumor growth in vivo (SAMADI et al., 2012; SAMADI, 2015). Furthermore, the present findings show that ethanolic extract was able to induce strong activity on the human lung carcinoma cell line A549 at 100 $\mu \mathrm{g} \mathrm{mL}^{-1}\left(0.4 \pm 1.3\right.$ of viability) and $10 \mu \mathrm{g} \mathrm{mL}^{-1}(70.0$ 
Table 2 - Ethanolic extracts exhibiting cell growth lesser than $\leq 50 \%$ at $10 \mu \mathrm{g} \mathrm{mL}^{-1}$ in at least one cell line $24 \mathrm{~h}$ exposure time.

\begin{tabular}{|c|c|c|c|c|c|c|}
\hline \multirow[t]{2}{*}{ Plant } & \multicolumn{6}{|c|}{ 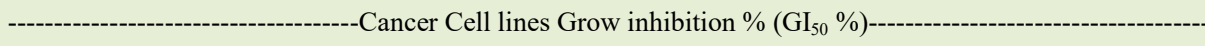 } \\
\hline & Caco2 & HepG2 & MCF7 & A549 & HEK-293 & B16 \\
\hline Azorella compacta & $90,3 \pm 5,8$ & $74,8 \pm 3,0$ & $50,0 \pm 9,0^{*}$ & $70,0 \pm 5,5$ & $43,6 \pm 14,2^{*}$ & $11,4 \pm 7,1^{*}$ \\
\hline Cynodon dactylon & $98,1 \pm 8,6$ & $31,8 \pm 5,1^{*}$ & $102,0 \pm 9,1$ & $88,7 \pm 7,8$ & $109,8 \pm 25,4$ & $79,4 \pm 4,2$ \\
\hline Dunalia spinosa & $103,0 \pm 6,4$ & $85,6 \pm 3,8$ & $90,8 \pm 5,0$ & $88,1 \pm 6,9$ & $68,4 \pm 10,9$ & $38,0 \pm 6,6^{*}$ \\
\hline Polylepis tarapacana & $93,1 \pm 16,1$ & $71,4 \pm 2,7$ & $113,3 \pm 7,1$ & $80,2 \pm 12,3$ & $95,4 \pm 13,9$ & $51,8 \pm 3,7$ \\
\hline Psoralea glandulosa & $95,0 \pm 4,5$ & $71,2 \pm 5,5$ & $91,2 \pm 7,7$ & $107,6 \pm 5,4$ & $98,6 \pm 9,4$ & $44,5 \pm 6,2^{*}$ \\
\hline Rosmarinus officinalis & $106,1 \pm 16,5$ & $83,1 \pm 9,8$ & $79,3 \pm 20,3$ & $69,0 \pm 16,5$ & $59,0 \pm 11,7$ & $30,0 \pm 8,3^{*}$ \\
\hline Doxorubicin & $113,0 \pm 2,1$ & $70,9 \pm 5,4$ & $110,8 \pm 5,1$ & $60,3 \pm 0,9$ & $50,5 \pm 8,1$ & $40,0 \pm 6,2$ \\
\hline
\end{tabular}

Note: $\mathrm{GI}_{50}$ : Grown Inhibition 50. The values were expressed as mean $\pm \mathrm{SD}(\mathrm{n}=6)$. Doxorubicin was considered as control drug ( $\mathrm{n}=3$ ).

*One way-ANOVA with $\mathrm{p}<0.05$ was considered as statistically significant difference.

\pm 5.5 ), opening new possibilities for new anticancer applications. The $R$. officinalis extract showed good activity at $10 \mu \mathrm{g} \mathrm{mL}^{-1}$, decreasing the cell viability $(30,0 \pm 8,3)$ of melanoma B16 and kidney HEK-293 cell lines. This effect is supported by previous results where the extract shows complementary activity as an agent in anticancer therapy (GONZÁLEZVALLINAS et al., 2015), specifically against two Human melanoma cell lines, M14 and A375.

Moreover, the $R$. officinalis extract has shown a protective effect on plasmid DNA damage (RUSSO et al., 2009). Also, studies of the whole extract suggest possessing antiproliferative activity, not attributed to the main chemical constituents isolated such as carnosic acid, carnosol, ursolic acid and rosmarinic acid (HUANG et al., 1994; CATTANEO et al., 2015; ANDRADE et al., 2018; BOURHIA et al., 2019). Other authors have demonstrated a differential cytotoxic effect of $C$. dactylon, being effective on laryngeal HEP-2, cervical HELA and MCF7 cancer cell lines but with minimum effect on monkey kidney Vero cells (KANIMOZHI, 2012; AL-SNAFI, 2016). The extract showed strong activity on MCF7, recording a $50 \%$ of anticancer activity at the concentration of 0.625 $\mu \mathrm{g} \mathrm{mL}^{-1}$, in comparison to the present work where no activity was detected. Other interesting cases are the extracts of $P$. glandulosa that in the present work induced cytotoxic activity on B16 melanoma cell line. Authors have reported activity of the aerial parts exudate from such plant able to inhibit the growth of A2058 melanoma cells with an $\mathrm{IC}_{50}$ value of 10.5 $\mu \mathrm{g} \mathrm{mL} \mathrm{mL}^{-1}$ after 48 hours of treatment (MADRID et al., 2015). Moreover, bakuchiol acetate, an isolated meroterpene from this plant was tested, exhibiting a major cytotoxic effect against melanoma cells. The present work reveals additional potential as a natural source to be studied on HEK-293 kidney cells showing strong activity at $100 \mu \mathrm{g} \mathrm{mL}^{-1}(5.3 \pm 2.2$ of viability) linked to the decrease on viability up to $68.4 \pm 10.9$.

Our results indicated that five of the 26 studied ethanolic extracts from highland species in northern Chile shows strong activity at least in one cell line tested at $10 \mathrm{~g} \mathrm{~mL}^{-1}$ in a first stage (Table 2). In a second line, our findings present five plants worthy to be evaluated as promissory ethanolic extracts with cytotoxic activity, in spite not to be considerably strong at $10 \mu \mathrm{g} \mathrm{mL} \mathrm{mL}^{-1}$. Further efforts will be made to analyze the $\mathrm{IC}_{50}$ values and also to extend the treatment times from 24 to 48 and $72 \mathrm{~h}$ to obtain more reliable results that can lead us to find biologically active extracts to perform fractioning and isolation of the active compounds. This work is the first glance and part of a systematic attempt to screen the cytotoxic activity of Andean plants looking for new candidates to be used in cancer therapies.

\section{ACNOWLEDGEMENTS}

This study was supported by CONICYT PRFC0005 and FONDECYT 1180059.

\section{DECLARATION OF CONFLICT OF INTERESTS}

The authors declare no conflict of interest. The funding sponsors had no role in the design of the study; in the collection, analyses, or interpretation of data; in the writing of the manuscript, and in the decision to publish the results.

\section{AUTHOR'S CONTRIBUTIONS}

All authors contributed equally for the conception and writing of the manuscript. All authors critically revised the manuscript and approved the final versión. 


\section{REFERENCES}

AL-SNAFI, A. Chemical constituents and pharmacological effects of Cynodon dactylon-A Review. IOSR Journal of Pharmacy, v.6, p.17-31. 2016. Available from: <http://iosrphr.org/papers/v6i7V2/ D06721731.pdf>. Accessed: Mar. 13, 2019. doi: 10.9790/301306721731 .

ANDRADE, J. M., et al. Rosmarinus officinalis L.: an update review of its phytochemistry and biological activity. Future science OA, v.4, n.4, p.FSO283-FSO283. 2018. Available from: $<$ https://www.ncbi.nlm.nih.gov/pmc/articles/PMC5905578/>. Accessed: Mar. 13, 2019. doi: 10.4155/fsoa-2017-0124.

BÓRQUEZ, J., et al. Isolation of cytotoxic diterpenoids from the Chilean medicinal plant Azorella compacta Phil from the Atacama Desert by high-speed counter-current chromatography. Journal of the Science of Food and Agriculture, v.96, n.8, p.2832-2838. 2016. Available from: <http://dx.doi.org/10.1002/jsfa.7451>. Accessed: Apr. 10, 2019. doi: 10.1002/jsfa.7451.

BOURHIA, M., et al. Antioxidant and Antiproliferative Activities of Bioactive Compounds Contained in $<\mathrm{i}>$ Rosmarinus officinalis $</ i>$ Used in the Mediterranean Diet. Evidence-Based Complementary and Alternative Medicine, v.2019, p.7623830. 2019. Available from: <https://doi.org/10.1155/2019/7623830>. Accessed: Apr. 10, 2019. doi: 10.1155/2019/7623830.

CATTANEO, L., et al. Anti-Proliferative Effect of Rosmarinus officinalis L. Extract on Human Melanoma A375 Cells. PLOS ONE, v.10, n.7, p.e0132439. 2015. Available from: <https://doi. org/10.1371/journal.pone.0132439>. Accessed: Apr. 12, 2019. doi: 10.1371/journal.pone.0132439.

CISTERNINO, S., et al. Nonlinear accumulation in the brain of the new taxoid TXD258 following saturation of P-glycoprotein at the blood-brain barrier in mice and rats. British Journal of Pharmacology, v.138, n.7, p.1367-1375. 2003. Available from: <https://bpspubs.onlinelibrary.wiley.com/doi/abs/10.1038/ sj.bjp.0705150>. Accessed: Apr. 18, 2019. doi: doi: 10.1038/ sj.bjp. 0705150 .

ECHIBURU-CHAU, C., et al. High resolution UHPLC-MS characterization and isolation of main compounds from the antioxidant medicinal plant Parastrephia lucida (Meyen). Saudi Pharmaceutical Journal, v.25, n.7, p.1032-1039. 2017. Available from: $<$ http://www.sciencedirect.com/science/article/pii/ S1319016417300579>. Accessed: Apr. 20, 2019. doi: 10.1016/j. jsps.2017.03.001.

ECHIBURÚ-CHAU, C. A.-L., S; et al.,. The selective cytotoxicity elicited by phytochemical extract from Senecio graveolens (Asteraceae) on breast cancer cells is enhanced by hypoxia. International Journal of Oncology, v.44, p.1357-1364. 2014. Available from: <https://www.spandidos-publications. com/ijo/44/4/1357>. Accessed: Apr. 22, 2019. doi: 10.3892/ ijo.2014.2302.

ERAZO, S., et al. Active Metabolites from Dunalia spinosa Resinous Exudates. Zeitschrift für Naturforschung. C, Journal of biosciences, v.63, p.492-6. 2008. Available from: $<\mathrm{https}$ :// www.degruyter.com/view/journals/znc/63/7-8/article-p492.xml>. Accessed: May, 03, 2019. doi: 10.1515/znc-2008-7-804

FERREIRA-MACHADO, S. C., et al. Genotoxic potentiality of aqueous extract prepared from Chrysobalanus icaco
L. leaves. Toxicology Letters, v.151, n.3, p.481-487. 2004. Available from: <http://www.sciencedirect.com/science/article/pii/ S0378427404001717>. Accessed: May, 08, 2019. doi: 10.1016/j. toxlet.2004.03.014.

FULDA, S. Betulinic Acid for cancer treatment and prevention. International journal of molecular sciences, v.9, n.6, p.10961107. 2008. Available from: <https://www.ncbi.nlm.nih.gov/pmc/ articles/PMC2658785/>. Accessed: May, 14, 2019. doi: 10.3390/ ijms 9061096 .

GARCÍA-ZEPEDA, S. P., et al. Resveratrol induces cell death in cervical cancer cells through apoptosis and autophagy. European Journal of Cancer Prevention, v.22, n.6, p.577-584. 2013. Available from: <https://journals.lww.com/eurjcancerprev/ Fulltext/2013/11000/Resveratrol_induces_cell_death_in cervical_cancer.13.aspx $>$. Accessed: May, 18, 2019. doi: $10 . \overline{1097 /}$ CEJ.0b013e328360345f.

GONZÁLEZ-VALLINAS, M., et al. Rosemary (Rosmarinus officinalis L.) Extract as a Potential Complementary Agent in Anticancer Therapy. Nutrition and Cancer, v.67, n.8, p.1223-1231. 2015. Available from: <http://dx.doi.org/10.10 80/01635581.2015.1082110>. Accessed: May, 19, 2019. doi: 10.1080/01635581.2015.1082110.

HUANG, M., et al. Inhibition of skin tumorigenesis by rosemary and its constituents carnosol and ursolic acid. Cancer research, v.54, p.701-8. 1994. Available from: <https://cancerres aacrjournals.org/content/54/3/701.long $>$. Accessed: Jun. 03, 2019.

JIMENEZ DE LA JARA, J., et al. A snapshot of cancer in Chile: analytical frameworks for developing a cancer policy. Biol Res, v.48, p.10. 2015. Available from: $<$ https://biolres.biomedcentral. com/articles/10.1186/0717-6287-48-10>. Accessed: Jun. 05, 2019. doi: 10.1186/0717-6287-48-10.

KANIMOZHI, D. In-Vitro Anticancer Activity of Ethanolic Extract of Cynodon dactylon Against HEP-2, HELA and MCF-7 Cell Lines. International Journal of Scientific Research and Reviews, v.1, n.1, p.10-23. 2012. Available from: <http://ijsrr.org/ down_122.php>. Accessed: Jun. 10, 2019.

KUMAR, P., et al. Analysis of Cell Viability by the MTT Assay. Cold Spring Harbor Protocols, v.2018, n.6, p.pdb. prot095505. 2018. Available from: <http://cshprotocols.cshlp. org/content/2018/6/pdb.prot095505.abstract>. Accessed: Jun. 13, 2019. doi: 10.1101/pdb.prot095505.

LÜ, S.; J. WANG. Homoharringtonine and omacetaxine for myeloid hematological malignancies. Journal of Hematology \& Oncology, v.7, n.1, p.2. 2014. Available from: $<$ https://doi. org/10.1186/1756-8722-7-2>. Accessed: Jun. 15, 2019. doi: $10.1186 / 1756-8722-7-2$.

MADRID, A., et al. Psoralea glandulosa as a potential source of anticancer agents for melanoma treatment. International journal of molecular sciences, v.16, n.4, p.7944-7959. 2015. Available from: $<$ https://www.ncbi.nlm.nih.gov/pmc/articles/PMC4425060/>. Accessed: Jun. 22, 2019. doi: 10.3390/ijms16047944.

MAKAROV, A. A., et al. Vinflunine, a Novel Microtubule Inhibitor, Suppresses Calmodulin Interaction with the Microtubule-Associated Protein STOP. Biochemistry, v.46, n.51, p.14899-14906. 2007. Available from: <https://doi.org/10.1021/ bi701803s $>$. Accessed: Jun. 24, 2019. doi: 10.1021/bi701803s. 
PARRA, C., et al. Nutritional composition, antioxidant activity and isolation of scopoletin from Senecio nutans: support of ancestral and new uses. Natural Product Research, v.32, n.6, p.719-722. 2018. Available from: <https://doi.org/10.10 80/14786419.2017.1335726>. Accessed: Jun. 24, 2019. doi: 10.1080/14786419.2017.1335726.

RUSSO, A., et al. Rosmarinus officinalis Extract Inhibits Human Melanoma Cell Growth. Natural product communications, v.4, p.1707-10. 2009. Available from: $\quad<$ https://journals.sagepub.com/doi/abs/10.1177/193 4578X0900401220>. Accessed: Jun. 24, 2019. doi: 10.1177/1934578X0900401220.

SAMADI, A. K. Potential Anticancer Properties and Mechanisms of Action of Withanolides. The Enzymes, v.37, p.73-94. 2015. Available from: <http://www.sciencedirect. com/science/article/pii/S1874604715000037>. Accessed: Jun. 24, 2019. doi: 10.1016/bs.enz.2015.05.002.
SAMADI, A. K., et al. Natural withanolide withaferin A induces apoptosis in uveal melanoma cells by suppression of Akt and c-MET activation. Tumor Biology, v.33, n.4, p.1179-1189. 2012. Available from: <https://doi.org/10.1007/s13277-012-0363-x>. Accessed: Jun. 24, 2019. doi: 10.1007/s13277-012-0363-X.

SOTO, E., et al. Potential of Baccharis alnifolia Meyen \& Walpan (Chilka) from northern Chile used as a medicinal infusion. Ciência Rural, v.49. 2019. Available from: <http:// www.scielo.br/scielo.php? script $=$ sci_arttext\&pid $=$ S010384782019001000401\&nrm=iso>. Accessed: Jun. 24, 2019. doi: $10.1590 / 0103-8478 \mathrm{cr} 20190428$

VILLAGRÁN, C., et al. Etnobotánica del sur de los andes de la primera región de chile: un enlace entre las culturas altiplánicas y las de quebradas altas del loa superior. chungará (arica), v.35, p.73-124. 2003. Available from: $<$ https://scielo.conicyt.cl/scielo.php?script=sci arttext\&pid=S0717-73562003000100005\&nrm=iso $>$. Accessed: Jun. 24, 2019. doi: 10.4067/S0717-73562003000100005. 